\title{
The International Standards for Solar Thermal Collectors and Components as a Medium of Quality Assurance
}

\author{
Nouri Alkishriwi', Christian A. Schorn ${ }^{2}$, and Danjana Theis ${ }^{3}$
}

${ }^{1}$ Department of Mechanical Engineering, University of Tripoli, Tripoli, Libya.

${ }^{2}$ C.A: Schorn Engineering UG, Solar thermal development and implementation of test facilities

${ }^{3} \mathrm{Head}$ of the test lab for solar thermal systems, TZSB der IZES gGmbH, c/o

Hochschultechnologiezentrum (HTZ) Altenkesseler Str. 17, Gebäude D2, D-66115

Saarbrücken-Germany

1e.mail: n.alkishriwi@yahoo.com, ${ }^{2}$ e.mail:Schorn@izes.de, and ${ }^{3}$ e.mail: $\underline{\text { theis@izes.de }}$

المللخص: تشتمل هذه الورقت على لمحت مفصلت حول المعايير والمواصفات القياسيت المحليت والدوليت الخاصت بالمجمعات والمنظومات الشمسيت. حيث سيتهم عرض مختلف الاختبارات القياسيت وتجارب الأداء الموضحت بهذه المواصفات المختلفت. كذلك سيتهم مناقشت المتطلبـات والشروط اللازم توافرها ِِّ مراكز اختبار المجمعات الشمسيت المعتمدة كطرف ثالث لإجراء الاختبـارات المختلفت ومن بعد تقييم النتائج بشكل مستقل, وذلك اعتمـادا على المواصفت الدوليت رقم IEC17025/ISO الخاصت باعتماد مـراكز الاختبـار. كذلك سيتم شـرح مفهوم نظام الجودة الخاص بالمجمعات الشمسيت وسرد المزايا الرئيسيت لهذا النظام. أيضا سيتم وصف وتبيان المجمعات الشمسيت ومنظومات تسخين المياه وتدفئت المباني ومكوناتها المختلفت سواء يْ المواصفات المحليت أو الدوليتة فمثلا يِّ أوروبا تعتبر المواصفت رقهم (EN12975) مختصت بتعريف اللوائح والمتطلبـات للهمجمعات الشمسيتة، بينما المواصفت رقهم (EN12976) مخصصتة للهنظومات الشمسيتة. أما المواصفت رقهم (EN12977) فقد صممت للمنظومات الشمسيت التي يتم تجميعها لغرض معين. مِ ليبيا حاليا تعتبر المواصفتان القياسيتان رقم (ISO9806) الخاصت بالمجمعات الشمسيت ورقهم (ISO9459) المخصصت لمنظومات تسـخين المياه هما المحددتان للوائح والمتطلبـات اللازم توافرها يِ المجمعات ومنظومات الطاقت الشمسيت الحراريتت. هِ غضون ذلك، يحاول مركز دراسـات الطاقت الشمسيت بليبيا إنثاء هيئت لإصدار شهادات كفاءة وجودة لمجمعات ومنظومات تسخحين المياه بالتعاون مع المركز الإقليهـي للطاقت المتجددة وكفاءة الطاقت (RCREEE). تعمل هذه الهيئت الآن على تحلديد الحد الأدنى من المتطلبـات الكلازم توافرها يِّ مـراكز اختبار المجمعات وأنظمهت الطاقت الشمسيتة. إلى جانب المواصفات القياسيت المختلفت للهمجمعات والمنظومات الشمسيت الحراريتت، ولضمان جودة هذه المنتجات ولحمايتً المستهليك فإن إصدار شهادة جهودة مـن طرف ثالث يعتبر أمـرا ضروريا. ولإصدار هذه الشهادة من الطرف الثالث فإنه لابد من إجراء

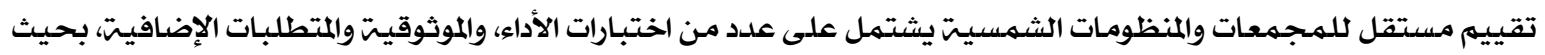
يتمم الوفاء بهذه المتطلبـات المحلدة بشأن هذه المجمعات والمنظومات. ففي أوروبا مثلا تقوم هيئت مستقلت حاصلت على الاعتماد 
وفقا للمواصفتَ رقم EN45011 بإصدار هذه الشهادات، بينما على المستوى الدولي فإن المواصفتر رقم IEC17065/ISO هي

المطلوبت.

وأخيرا ولضمان درجت عاليت من الجودة للمنتج ولحمايت المستهلك، فإن إنشاء نظام جودة معتمد من هيئت مستقلتة

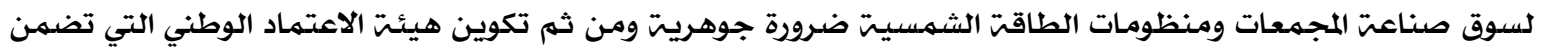
مطابقت مختلف المتطلبات والشهادات الصادرة من الجهات المعتمدة السابقت.

Abstract: Within this publication a detailed overview about the national and international solar thermal standards is made. The various tests are described and a cross reference list for comparing the different standards is given. Moreover a certification model is presented and the advantage of third party assessment is carried out. The requirement for a solar thermal test laboratory to conduct independent third party assessment by means of an ISO/IEC17025 accreditation is given. Finally the concept of a quality system for solar thermal markets is explained and major advantages are outlined.

Solar thermal systems and their components are described in various national and international standards. In Europe the standard EN12975 defines the regulations and requirements for solar thermal collectors. The standard EN12976 is established for the evaluation of factory made solar thermal systems. The EN12977 is the state of the art standard for the evaluation of custom build systems.

Nowadays in Libya the standard ISO9806 for solar collectors and the standard ISO9459 for domestic water heating systems define the regulations and requirements for solar thermal collectors and systems. In the meanwhile, empowered Center for Renewable Energy and Energy Efficiency Certification Body is under construction. This body is working now to set the minimum requirements of the testing facilities of solar thermal systems.

The international standard for collector testing is the ISO9806 and the standard ISO9459 Part 2, 4, 5 for domestic water heating systems. Within the year 2013 a revision of the ISO9806 will be published and, for the first time, a consistent harmonized standard for the main solar thermal markets will be set in force.

Besides the various standards for solar thermal products a meaningful element for the quality assurance and the customer protection is third party certification. Third party certification involves an independent assessment, declaring that specified requirements regarding a product are fulfilled. In a certification process based on specified certification rules an authorized certification body is confirming that a solar thermal product has passed performance tests, reliability tests and further requirements according to the standards. In Europe a certification body holds an accreditation according to EN45011. At international level the standard ISO/IEC17065 is in force.

Test results as a basis for product certification are determined by solar thermal test laboratories. The implementation and the business operation of such a solar thermal test laboratory is an important element within the national / regional solar thermal market. To 
ensure the quality of the products and to attend the role of an observer on the market, the test facility has to fulfill a number of requirements. Besides the necessary technical equipment and the implementation of tests in accordance with the various national and international standards, the laboratory shall realize a quality management system to guarantee the quality of tests and services. Based on the technical equipment, the testing scope and an implemented Quality Management System (QMS), the test laboratory can achieve an accreditation according to ISO/IEC17025 as basis for independent third party testing. Independent testing and evaluation of solar thermal collectors and components like hot water stores and controllers offers an important medium for quality assurance.

To guarantee a high degree of product quality and consumer protection a quality system for the solar thermal market is necessary. Core of the quality assurance of a functioning solar thermal market are the national standards body, which is developing standards and regulations as a working basis in technical committees, the national metrology institute that guarantees the traceability of measurements on fundamental and natural constants, and finally the national accreditation body which ensures the conformity of the various actors to a specific standard.

Laboratories work closely with the certification authorities and apply the developed specific norms and standards. The certification bodies must ensure the conformance of their test laboratories with the standard ISO/IEC17025, which include the quality standard ISO 9001:2008 and also include additional requirements.

The traceability of the metrics of solar thermal testing laboratories is usually made with the help of calibration laboratories that are specialized on certain measurements. Those are also accredited and ensure the traceability of their measurements to the national meteorology institute.

Other stakeholders are the group of importers and exporters and foreign investors who are on the national market in entrepreneurial activities, as well as the group of consumer organizations that represent the interests of customers. By means of good networking of stakeholders and focusing on the quality process, a high-quality and flourishing solar thermal market can be created.

Keywords: solar thermal standards, accreditation, certification

\section{INTRODUCTION}

Solar thermal applications offer a huge potential to contribute to the energy demand of the world. Solar thermal products can be used for residential applications, industrial processes as well as for electrical power generation. Beside the different kinds of pumps, pipes, valves, controllers and storages various sets of collector types are available. The most common used collectors are vacuum tube collectors, flat plate collectors, concentrating and tracking collectors and hybrid collectors, which deliver thermal and 
electrical power at the same time.

To guarantee technical safety, reliability, performance criteria as well as documentation for users and installers of the collector or system an evaluation process from an expert is necessary. Solar thermal test center can provide the technical equipment and the educated experts to conduct the quality assurance processes. Those processes should be based on international standards like the standard ISO9806 and the standard ISO9459 or based on a national or regional standards, in order to provide a high degree of transparency, acceptance and conformance.

Standards in common are an important element to provide the quality assurance of a certain product for the market and serve in order to ensure consumer protection. In general standards are establishing requirements and regulations for the evaluation and application of the products under examination. Moreover test methods are described and minimum requirements for the documentations are specified. Based on the test results a final assessment of the product can be carried out, which might result in recommendations for market regulations.

The development of standardization and certification differs around the world. Many countries still lack any sort of standards aimed at solar thermal products. It should be noted that solar thermal standards are mostly testing standards. In other sectors, there are product standards specifying how a product has to be built (e.g. certain minimum sizes, materials to be used, etc...). In the case of solar thermal this is not currently the case and standards detail how testing methods should be applied to such products.

\section{STANDARDS AND TEST METHODS FOR SOLAR THERMAL PRODUCTS}

Standards are defining rules, guidelines and characteristics of products or processes. They serve to unify and guarantee the quality assurance and consumer protection (efficiency of products, technical reliability). Standards are consensus-based and voluntary in contrast to technical regulations that are binding, such as regulations in the areas of health, safety, environment. Since 2000 there is a uniform harmonized European standard for solar thermal collectors, complete systems, storage systems and their components, respectively. The standards specify characteristics and minimum requirements for solar thermal products. In addition, the test methods for verifying the durability and reliability are defined and described in the test methods for determining the thermal performance.

Consumers, engineers and experts must be able to trust the information provided to them by their manufacturers or suppliers. The information must be comprehensible and mention the main parameters of the specific product. Moreover the results must be reproducible with the same measurement methods by different entities. The consumers should be able to have confidence in the results of the standards and be able to 
compare the products with respect to the price performance ratio.

For the authorities and policy makers, it is important to have legal instruments and incentive systems on hand. Only solar thermal collectors or solar thermal systems which meet the minimum requirements are sufficient for various incentive programs. Regarding legal issues, to meet the minimum requirements may play a role if it comes to malfunction and failure of systems. Within the standards the performance of the products is tested as well as the reliability of the products with respect to thermal, mechanical and environmental stress in order to ensure the safety and durability of the products. Table 1 gives an overview of some standards applied in the field of solar thermal systems and their status.

At the international level it is aimed that the EN series of standards for solar thermal systems to gradually convert to ISO standards. Currently the European Committee CEN/TC 312 is playing a leading role in the implementation of the relevant standards in the technical committee ISO/TC 180. The Vienna Convention, which controls the technical cooperation between the International Organization for Standardization (ISO) and the European Committee for Standardization (CEN) supports this project. This involves in particular the parallel acceptance of the work results of the standardization bodies and their simultaneous recognition as an international and a European standard. Stronger long-term harmonization of standards is desirable and sought an international certification process based on an ISO standard series for solar thermal systems and their components is beneficial for the stakeholder.

Table (1). Overview about the various Standards for Solar Thermal Products.

\begin{tabular}{|c|c|c|}
\hline $\begin{array}{c}\text { Identification of the } \\
\text { standard }\end{array}$ & \multicolumn{1}{c|}{$\begin{array}{c}\text { Title of the standard } \\
\text { Solar thermal products and components }\end{array}$} \\
\hline \multicolumn{1}{|c|}{ Solar thermal systems } \\
\hline ISO 9459-2 & $\begin{array}{l}\text { Systems-Part 2: Outdoor test methods for system } \\
\text { performance characterization and yearly } \\
\text { performance prediction of solar-only systems }\end{array}$ & CSTG - method \\
\hline ISO 9459-5 & $\begin{array}{l}\text { Solar heating - Domestic water heating systems- } \\
\text { Part5: System performance characterization } \\
\text { by means of whole-system tests and computer } \\
\text { simulation }\end{array}$ & Date: 1995-08 \\
\hline EN12976- 1 & $\begin{array}{l}\text { Shermal solar systems and components. Factory } \\
\text { made systems. General requirements }\end{array}$ & Date: 2007-05 \\
\hline
\end{tabular}




\begin{tabular}{|c|c|c|}
\hline EN12976- 2 & $\begin{array}{l}\text { Thermal solar systems components. Factory made } \\
\text { systems. Test methods }\end{array}$ & $\begin{array}{l}\text { European standard } \\
\text { English version } \\
\text { Date: } 2006-04\end{array}$ \\
\hline ASHRAE 93 & $\begin{array}{l}\text { Methods of testing to determine the thermal } \\
\text { performance of solar collectors }\end{array}$ & $\begin{array}{c}\text { ANSI approved } \\
\text { English version. Date: } 2010\end{array}$ \\
\hline ASHRAE 96 & $\begin{array}{l}\text { Methods of testing to determine the thermal } \\
\text { performance of unglazed flat-plate liquid-type } \\
\text { solar collectors }\end{array}$ & $\begin{array}{c}\text { ANSI approved } \\
\text { English version } \\
\text { Date: } 1980 \text { (RA 1989) }\end{array}$ \\
\hline \multicolumn{3}{|c|}{ Solar thermal collectors } \\
\hline ISO/DIS $9806-1 / 2 / 3$ & $\begin{array}{l}\text { Solar energy - Solar thermal collectors - Test } \\
\text { methods }\end{array}$ & Draft 2012-04 \\
\hline EN12975- 1 & $\begin{array}{l}\text { Thermal solar systems and components. Solar } \\
\text { collectors. General requirements }\end{array}$ & $\begin{array}{l}\text { European standard } \\
\text { English version } \\
\text { Date: } 2006+\text { A1:2010 } \\
\text { Continuous revision }\end{array}$ \\
\hline EN12975- 2 & $\begin{array}{l}\text { Thermal solar systems and components. Solar } \\
\text { collectors. Test methods }\end{array}$ & $\begin{array}{l}\text { European standard } \\
\text { English version } \\
\text { Date: } 2006-04\end{array}$ \\
\hline EN12975 - 3-1 & $\begin{array}{l}\text { Thermal solar systems and components. Solar } \\
\text { collectors. Part 3-1. Qualification of solar absorber } \\
\text { surface durability }\end{array}$ & $\begin{array}{l}\text { Draft } \\
\text { English version } \\
\text { Date: } 2011-08\end{array}$ \\
\hline \multicolumn{3}{|c|}{ Custom made systems } \\
\hline EN12977- 1 & $\begin{array}{l}\text { Thermal solar systems and components. Custom } \\
\text { built systems. General requirements for solar } \\
\text { water heaters and combisystems }\end{array}$ & $\begin{array}{l}\text { European standard } \\
\text { English version } \\
\text { Date: } 2012-04\end{array}$ \\
\hline EN12977- 2 & $\begin{array}{l}\text { Thermal solar systems and components. Custom } \\
\text { built systems. Test methods for solar water heaters } \\
\text { and combisystems }\end{array}$ & $\begin{array}{l}\text { European standard } \\
\text { English version } \\
\text { Date: } 2012-04\end{array}$ \\
\hline EN12977- 3 & $\begin{array}{l}\text { Thermal solar systems and components. Custom } \\
\text { built systems. Performance test methods for solar } \\
\text { water heater stores }\end{array}$ & $\begin{array}{l}\text { European standard } \\
\text { English version } \\
\text { Date: } 2012-04\end{array}$ \\
\hline EN12977- 4 & $\begin{array}{l}\text { Thermal solar systems and components. Custom } \\
\text { built systems. Performance test methods for solar } \\
\text { combistores }\end{array}$ & $\begin{array}{l}\text { European standard } \\
\text { English version } \\
\text { Date: } 2012-04\end{array}$ \\
\hline
\end{tabular}




\begin{tabular}{|c|l|c|}
\hline EN12977-5 & $\begin{array}{l}\text { Thermal solar systems and components. Custom } \\
\text { built systems. Performance test methods for } \\
\text { control equipment }\end{array}$ & $\begin{array}{c}\text { European standard } \\
\text { English version }\end{array}$ \\
\hline ISO 9459-4 & $\begin{array}{l}\text { Solar heating - domestic water heating systems } \\
- \text { Part 4: System performance by means of } \\
\text { component tests and computer simulation }\end{array}$ & International standard \\
\hline
\end{tabular}

The new standard is supposed to be in charge between February and May 2014. The EN ISO9806 is going to substitute the EN12975-2 and the ISO9806-1, 2, 3. It will be the first almost globally valid standard for solar thermal collectors, as it is both an EN and an ISO standard [1].

Nowadays in Libya the standard ISO9806 for solar collectors and the standard ISO9459 for domestic water heating systems define the regulations and requirements for solar thermal collectors and systems. To my best knowledge and according to the information from the Centre for Solar Energy Research and Studies (CSERS) and Libyan National Center for Standardization and Metrology (LNCSM), there is no local standard that defines the regulations and requirements for solar thermal collectors and systems in Libya. In the meanwhile, empowered Center for Renewable Energy and Energy Efficiency Certification Body is under construction. This body is working now to set the minimum requirements of the testing facilities of solar thermal systems.

\section{SOLAR THERMAL COLLECTOR TEST STANDARDS-CROSS REFERENCE LIST}

Most of the existing standards for solar thermal products are mainly testing standards. Therefore these standards provide guidelines for procedures to be followed when testing solar thermal products.

Table 2 provides an overview and comparison of the requirements described in some of the solar thermal standards commonly used today. These compare testing requirements related to: High temperature resistance, Exposure, External thermal shock, Internal thermal shock, Rain penetration, Impact resistance, Mechanical Load, Final inspection, and Thermal performance.

\section{THE ROLE OF THIRD PARTY CERTIFICATION IN SOLAR THERMAL MARKETS}

Certification of products plays internationally an increasing role, as hereby the access to markets can be unified and accelerated in one side and to ensure that products in the market conform with standards on the other side.

Certification is the independent verification that a product, a component of a product, a procedure, a process or a company meets specific criteria. This is usually confirmed by a label, seal or sign. Such is awarded by institutions which are internationally accredited according to ISO/IEC17065, which is used also in Libya. In Europe the EN45011 is in force for the requirements of a certification body [1]. 
An important part of the certification process is the independence of the assessment, which is also called third party testing. Moreover an independent sampling of the products to be tested is necessary in combination with an initial inspection.

In the field of solar thermal energy in Europe the "Solar Keymark" label [2], developed by the European Solar Thermal Industry Federation (ESTIF) and the Committee for Standardization CEN, is enforced since 2003. It standardizes the test procedures and ensures the quality of solar products. The mark is available for solar collectors based on European standard series EN12975 and for factory made solar thermal systems based on European standard series EN12976 and since 2013 for custom made solar thermal systems according to the EN12977 series.

In North America the SRCClabel from the Solar Rating and Certification Cooperation is valid for the solar thermal market. This label is also obtainable for solar collectors and for factory made solar thermal systems. The scope of the program for collectors contains collectors and absorbers for various applications. The program is based on SRCC Document OG-100, "Operating Guidelines for Certifying Solar Collectors," and its companion document, SRCC Standard 100, "Test Methods and Minimum Standards for Certifying Solar Collectors" [3]. The tests are adapted by standard ASHRAE 93 and ASHRAE 96. The scope of the program for factory made systems is organized under the OG-300 protocol. In ten steps the certification can be done based on documentation criteria, labeling criteria and performance data from the collector in combination with a TRNSYS calculation. The tests according to both programs can be carried out by accredited test laboratories that are approved by SRCC.

At the end of 2011, the Arab Ministerial Council for Electricity (AMCE) asked the Regional Center for Renewable Energy and Energy Efficiency (RCREEE) and the Arabian Industrial Development and Mining Organization (AIDMO) to work on a standardization and certification program for SWHs to ensure a specific quality level for solar thermal products and services in the Arab region. The RCREEE worked on this request together with the University of Stuttgart in Germany. The final output - the SHAMCI (Solar Heaters Arab Mark and Certification Initiative) certification program - is similar to the Solar Keymark in Europe or the Solar Rating and Certification Corporation (SRCC) in the US. It was released at the end of 2012.

Nowadays the SHAMCI certification scheme is under development [4]. It is planned to establish a certification similar to the Solar Keymark certification scheme for the MENA (Middle East and North Africa) region. The objective of the SHAMCI is to strengthen the market transformation of solar collectors and systems in the MENA region, reduce trade barriers and promote the use of high quality solar thermal products in the region and beyond. In lead for the organization is the RECREE (Regional 
Centre for Renewable Energy and Energy Efficiency) in this day and a certification for solar collectors based on European standard series EN12975 and for factory made solar thermal systems based on European standard series EN12976 is planned. The test laboratories have to be approved by SHAMCI and are encouraged to get an accreditation until 2017. Table 3 shows the name and potential of RCREEE Members (countries) in the field Certification and Standardization [4]. From the table we can see that Libya is one of the RCREEE Member States. Many countries in this table including Libya still lack any sort of standards, certification system, Quality control regulations and rules aimed at solar thermal products. The Center of Solar Energy has a modern testing laboratory.

Table (2). Comparaison of Testing Requirements for Solar Thermal Collectors[1]

\begin{tabular}{|c|c|c|}
\hline Test & Standard & Test procedure \\
\hline \multirow{8}{*}{ Temperature } & EN 12975 & $\begin{array}{l}\text { Collector A minimum } 1 \mathrm{~h} \text { with } \mathrm{G}>1000 \mathrm{~W} / \mathrm{m}^{2} \text { and ambient } \\
\text { temperature } 20-40^{\circ} \mathrm{C} \text {, wind }<1 \mathrm{~m} / \mathrm{s}\end{array}$ \\
\hline & ISO 9806-1 & \\
\hline & ISO 9806-2 & $\begin{array}{l}\text { Collector A minimum } 1 \text { h with G: A) } 950-1049 \text {; B) } 1050-1200 \text {; C) } \\
>1200\left(\mathrm{~W} / \mathrm{m}^{2}\right) \text { and ambient temperature: A) } 25-29,9 \text {; B) } 30-40 \text {; } \\
\text { C) }>40{ }^{\circ} \mathrm{C} \text {, wind }<1 \mathrm{~m} / \mathrm{s}\end{array}$ \\
\hline & Standard 100-8 & \\
\hline & CAN/CSA-F378-87 & $\begin{array}{l}\text { Collector A minimum } 1,5 \mathrm{~h} \text { with } \mathrm{G}(\mathrm{I})=950+5^{\star}\left(30-\mathrm{T}_{\mathrm{amb}}\right) \mathrm{W} / \mathrm{m}^{2} \text {, } \\
\text { wind }<5 \mathrm{~m} / \mathrm{s}\end{array}$ \\
\hline & $\begin{array}{l}\text { ANSI/ASHRAE } \\
\text { standard } 93\end{array}$ & \\
\hline & AS/NZS 2735.1 & Collector A according to ISO 9806-2 \\
\hline & AS/NZS 2712 & $\begin{array}{l}\text { Collector A performance according to AS/NZS2535.1 } \mathrm{G}_{\text {mean }}=1050 \\
\mathrm{~W} / \mathrm{m}^{2} \text { with } \max 20 \mathrm{~W} / \mathrm{m}^{2} \text { deviation at } 6 \text { points } \mathrm{T}_{\text {amb }}>30^{\circ} \mathrm{C} \text { (Level } \\
\text { 1) } />38{ }^{\circ} \mathrm{C}(\text { Level } 2), 12 \mathrm{~h} \text { irradiation on } / 12 \mathrm{~h} \text { irradiation off for } \\
10 \text { days }\end{array}$ \\
\hline \multirow[t]{2}{*}{ Exposure } & EN 12975 & $\begin{array}{l}\text { Collector A according to ISO } 9806-2 \text { Class A } \\
30 \text { days with } \mathrm{G}>14 \mathrm{MJ} / \mathrm{m}^{2} \\
30 \mathrm{~h} \text { with } \mathrm{G}>850 \mathrm{~W} / \mathrm{m}^{2} \text { and } \mathrm{T}_{\mathrm{amb}}>10^{\circ} \mathrm{C}\end{array}$ \\
\hline & ISO 9806-1 & \\
\hline
\end{tabular}




\begin{tabular}{|c|c|c|}
\hline Test & Standard & Test procedure \\
\hline \multirow{6}{*}{ Exposure } & ISO 9806-2 & $\begin{array}{l}\text { Collector A, B, C } \\
30 \text { days with G: A) } 14 \text {; B) } 18 \text {; C) } 20 \mathrm{MJ} / \mathrm{m}^{2} \\
30 \text { h with G: A) } 850 \text {; B) } 950 \text {; C) } 1050 \mathrm{~W} / \mathrm{m}^{2} \\
\text { and } \mathrm{T}_{\mathrm{amb}}>\text { A) } 10 \text {; B) } 15 \text {; C) } 20^{\circ} \mathrm{C}\end{array}$ \\
\hline & Standard 100-8 & Collector A 30 days with $\mathrm{G}>17 \mathrm{MJ} / \mathrm{m}^{2}$ \\
\hline & CAN/CSA-F378-87 & $\begin{array}{l}\text { Collector A, first the collector will be filled according to } \mathrm{Ba} / \mathrm{Bb} / \mathrm{Bc} \\
\text { drain and close. Exposition phase started after closing of pipes } 30 \\
\text { days with } \mathrm{G}>17 \mathrm{MJ} / \mathrm{m}^{2}\end{array}$ \\
\hline & $\begin{array}{l}\text { ANSI/ASHRAE } \\
\text { standard } 93\end{array}$ & \\
\hline & AS/NZS 2735.1 & Collector A according to ISO 9806-2 \\
\hline & AS/NZS 2712 & \\
\hline \multirow{8}{*}{ Thermal Shock } & EN 12975 & $\begin{array}{l}\text { Collector A } 2 \text { times according to ISO } 9806-2 \text { Class A minimum } 1 \mathrm{~h} \\
\text { with } \mathrm{G}\left(\mathrm{W} / \mathrm{m}^{2}\right) \text { and } \mathrm{T}_{\mathrm{amb}}\left({ }^{\circ} \mathrm{C}\right) \text { as in } 30 \mathrm{~h} \text { exposure }\end{array}$ \\
\hline & ISO 9806-1 & \\
\hline & ISO 9806-2 & $\begin{array}{l}\text { Collector A } 2 \text { times minimum } 1 \mathrm{~h} \text { with } \mathrm{G}\left(\mathrm{W} / \mathrm{m}^{2}\right) \text { and } \mathrm{T}_{\mathrm{amb}}\left({ }^{\circ} \mathrm{C}\right) \text { as } \\
\text { in } 30 \mathrm{~h} \text { exposure }\end{array}$ \\
\hline & Standard 100-8 & $\begin{array}{l}\text { Collector A } 3 \text { times according to ISO 9806-2 Class B minimum } 1 \mathrm{~h} \\
\text { with } \mathrm{G}>950 \mathrm{~W} / \mathrm{m}^{2} \text { and } \mathrm{T}_{\mathrm{amb}}>15^{\circ} \mathrm{C}\end{array}$ \\
\hline & CAN/CSA-F378-87 & \\
\hline & $\begin{array}{l}\text { ANSI/ASHRAE } \\
\text { standard } 93\end{array}$ & \\
\hline & AS/NZS 2735.1 & Collector A according to ISO 9806-2 \\
\hline & AS/NZS 2712 & \\
\hline Internal & EN 12975 & $\begin{array}{l}\text { Collector A } 2 \text { times according to ISO 9806-2 Class A minimum } 1 \mathrm{~h} \\
\text { with } \mathrm{G}\left(\mathrm{W} / \mathrm{m}^{2}\right) \text { and } \mathrm{T}_{\mathrm{amb}}\left({ }^{\circ} \mathrm{C}\right) \text { as in } 30 \mathrm{~h} \text { exposure }\end{array}$ \\
\hline Thermal Shock & ISO 9806-1 & \\
\hline
\end{tabular}




\begin{tabular}{|c|c|c|}
\hline Test & Standard & Test procedure \\
\hline \multirow{6}{*}{ Thermal Shock } & ISO $9806-2$ & $\begin{array}{l}\text { Collector A } 2 \text { times minimum } 1 \mathrm{~h} \text { with } \mathrm{G}\left(\mathrm{W} / \mathrm{m}^{2}\right) \text { and } \mathrm{T}_{\mathrm{amb}}\left({ }^{\circ} \mathrm{C}\right) \text { as } \\
\text { in } 30 \mathrm{~h} \text { exposure }\end{array}$ \\
\hline & Standard $100-8$ & $\begin{array}{l}\text { Collector A } 1 \text { time according to ISO 9806-2 Class B } \\
\text { minimum } 1 \mathrm{~h} \text { with } \mathrm{G}>950 \mathrm{~W} / \mathrm{m}^{2} \text { and } \mathrm{T}_{\mathrm{amb}}>15^{\circ} \mathrm{C}\end{array}$ \\
\hline & CAN/CSA-F378-87 & Collector A 1 time minimum $1 \mathrm{~h}$ with $\mathrm{G}>900 \mathrm{~W} / \mathrm{m}^{2}$ \\
\hline & $\begin{array}{l}\text { ANSI/ASHRAE } \\
\text { standard } 93\end{array}$ & \\
\hline & AS/NZS 2735.1 & Collector A according to ISO 9806-2 \\
\hline & AS/NZS 2712 & \\
\hline \multirow{8}{*}{ Penetration } & EN 12975 & Collector A, Test duration $4 \mathrm{~h}$ \\
\hline & ISO 9806-1 & \\
\hline & ISO 9806-2 & Collector A, Test duration $4 \mathrm{~h}$ \\
\hline & Standard $100-8$ & \\
\hline & CAN/CSA-F378-87 & Collector A, Test duration $30 \mathrm{~min}$. \\
\hline & $\begin{array}{l}\text { ANSI/ASHRAE } \\
\text { standard } 93\end{array}$ & \\
\hline & AS/NZS 2735.1 & Collector A according to ISO 9806-2 \\
\hline & AS/NZS 2712 & $\begin{array}{l}\text { Collector A } 10 \text { min. rain penetration, } 4 \mathrm{~h} \text { drying with shaded } \\
\text { aperture }\end{array}$ \\
\hline \multirow[b]{3}{*}{ Resistance } & EN 12975 & $\begin{array}{l}\text { Collector A according to ISO } 9806-2 \text { or with } 7.5 \mathrm{~g} \text { ice ball } 10 \text { times } \\
\text { with } 23 \mathrm{~m} / \mathrm{s} \pm 5 \%\end{array}$ \\
\hline & ISO $9806-1$ & \\
\hline & ISO 9806-2 & $\begin{array}{l}\text { Collector A or B max. } 5 \mathrm{~cm} \text { from the edge max. } 10 \mathrm{~cm} \text { from the } \\
\text { corner. Steel ball } 150 \text { gram }+/-10 \text { geach } 10 \text { times at } \\
0,4 / 0,6 / 0,8 / 1,0 / 1,2 / 1,4 / 1,6 / 1,8 / 2,0 \text { meter in height }\end{array}$ \\
\hline
\end{tabular}




\begin{tabular}{|c|c|c|}
\hline Test & Standard & Test procedure \\
\hline \multirow{5}{*}{$\begin{array}{c}\text { Impact } \\
\text { Resistance }\end{array}$} & Standard $100-8$ & Collector A according to ISO 9806-2 for none tempered glass \\
\hline & CAN/CSA-F378-87 & \\
\hline & $\begin{array}{l}\text { ANSI/ASHRAE } \\
\text { standard } 93\end{array}$ & \\
\hline & AS/NZS 2735.1 & Collector A according to ISO 9806-2 \\
\hline & AS/NZS 2712 & $\begin{array}{l}\text { Collector A - no glass pieces }>50 \mathrm{~mm} \text { with ice ball according to EN } \\
12975 \text { with steel ball } 63 \text { gram at } 2.9 \mathrm{~m} \text { height, } 3 \text { different positions, } \\
150 \mathrm{~mm} \text { from corner or edge }\end{array}$ \\
\hline \multirow{8}{*}{$\begin{array}{l}\text { Mechanical } \\
\quad \text { Load }\end{array}$} & EN 12975 & Collector A minimum $+1000 \mathrm{~Pa}$, minimum $-1000 \mathrm{~Pa}$ \\
\hline & ISO $9806-1$ & \\
\hline & ISO $9806-2$ & \\
\hline & Standard 100-8 & \\
\hline & CAN/CSA-F378-87 & Collector A + $1500 \mathrm{~Pa},-2000 \mathrm{~Pa}$ \\
\hline & $\begin{array}{l}\text { ANSI/ASHRAE } \\
\text { standard } 93\end{array}$ & \\
\hline & AS/NZS 2735.1 & \\
\hline & AS/NZS 2712 & Collector A positive and negative load \\
\hline \multirow{8}{*}{ Inspection } & EN 12975 & Collector A \\
\hline & ISO $9806-1$ & \\
\hline & ISO $9806-2$ & Collector A, B, C \\
\hline & Standard 100-8 & Collector A \\
\hline & CAN/CSA-F378-87 & Collector A \\
\hline & $\begin{array}{l}\text { ANSI/ASHRAE } \\
\text { standard } 93\end{array}$ & \\
\hline & AS/NZS 2735.1 & Collector A \\
\hline & AS/NZS 2712 & \\
\hline
\end{tabular}




\begin{tabular}{|c|c|c|}
\hline Test & Standard & Test procedure \\
\hline \multirow{8}{*}{$\begin{array}{c}\text { Thermal } \\
\text { Performance }\end{array}$} & EN 12975 & $\begin{array}{l}\text { Collector B, pre-conditioning } 5 \mathrm{~h} \text { with } \mathrm{G}>700 \mathrm{~W} / \mathrm{m}^{2} \text {, diffuse } \\
\text { fraction }<30 \% \text {. Steady State or Quasi-Dynamic Testing. }\end{array}$ \\
\hline & ISO 9806-1 & $\begin{array}{l}\text { Collector } \mathrm{A} \text {, tilt-angle latitude } \pm 5^{\circ} \text { but not less than } 30^{\circ} \text {, diffuse } \\
\text { fraction }<20 \% \text {. Collector area: } 0.1 \% \text { accuracy, minimum global } \\
\text { irradiation } \mathrm{G}>800 \mathrm{~W} / \mathrm{m}^{2} \text {. Wind speed } 2-4 \mathrm{~m} / \mathrm{s} \text {. Volume flow } 0.02 \\
\mathrm{~kg} /\left(\mathrm{s}^{*} \mathrm{~m}^{2}\right) \text {, max. drift }+/-10 \% \text {, deviation mass flow } \pm 1 \% \text {, Deviation } \\
\text { Irradiation } \pm 50 \mathrm{~W} / \mathrm{m}^{2} \text {. Deviation } \mathrm{T}_{\mathrm{amb}} \pm 1 \mathrm{~K} \text {, deviation inlet } \\
\text { temperature } \pm 0.1 \mathrm{~K} \text {. } \mathrm{T}_{\text {out }}-\mathrm{T}_{\text {in }}>1.5 \mathrm{~K}, \mathrm{~T}_{\mathrm{m}}-\mathrm{T}_{\text {amb }} \text { at } \eta_{0} \pm 3 \mathrm{~K} \text {. Conditioning } \\
\text { phase minimum } 15 \mathrm{~min} \text { and measurement phase minimum } 15 \text { min. }\end{array}$ \\
\hline & ISO 9806-2 & Collector A according to ISO 9806-1 \\
\hline & Standard 100-8 & $\begin{array}{l}\text { Collector A, } 5 \text { minutes measurement points } / 0.07 \mathrm{~g} /\left(\mathrm{s}^{*} \mathrm{~m}^{2}\right) \\
\text { according to ISO } 9806-1\end{array}$ \\
\hline & CAN/CSA-F378-87 & Collector A according to ANSI/ASHRAE \\
\hline & $\begin{array}{l}\text { ANSI/ASHRAE } \\
\text { standard } 93\end{array}$ & $\begin{array}{l}\text { Minimum global irradiation } \mathrm{G}>790 \mathrm{~W} / \mathrm{m}^{2} \text {, deviation irradiation } \pm \\
32 \mathrm{~W} / \mathrm{m}^{2} \text {, diffuse fraction }<20 \% \text {. Max. } \mathrm{T}_{\mathrm{amb}} 30^{\circ} \mathrm{C} \text {. Wind speed } 2.2 \\
-4.5 \mathrm{~m} / \mathrm{s} \text {, volume flow } 0.02 \mathrm{~g} /\left(\mathrm{s}^{\star} \mathrm{m}^{2}\right) \text {. Deviation inlet temperature } \\
\pm 2 \% \text { or } 1{ }^{\circ} \mathrm{C} \text { Deviation mass flow } \pm 2 \% \text { or } 0.000315 \mathrm{l} / \mathrm{s} \text {. Deviation } \\
\mathrm{T}_{\mathrm{amb}} \pm 1,5 \mathrm{~K} \text {. Conditioning phase } 2^{\star} \text { times constant or minimum } \\
10 \text { minutes. Measurement phase minimum } 0.5^{\star} \text { times constant or } \\
\text { minimum } 5 \text { minutes. }\end{array}$ \\
\hline & AS/NZS 2735.1 & $\begin{array}{l}\text { Collector } \mathrm{A} \text {, tilt-angle latitude } \pm 5^{\circ} \text { but not less than } 30^{\circ} \text {, diffuse } \\
\text { fraction }<20 \% \text {. Collector area: } 0.1 \% \text { accuracy, minimum global } \\
\text { irradiation } \mathrm{G}>800 \mathrm{~W} / \mathrm{m}^{2} \text {. Wind speed } 2-4 \mathrm{~m} / \mathrm{s} \text {. Volume flow } \\
0.02 \mathrm{~kg} /\left(\mathrm{s}^{\star} \mathrm{m}^{2}\right) \text {, max. drift }+/-10 \% \text {, deviation mass flow } \pm 1 \% \text {, } \\
\text { Deviation Irradiation } \pm 50 \mathrm{~W} / \mathrm{m}^{2} . \text { Deviation } \mathrm{T}_{\mathrm{amb}} \pm 1 \mathrm{~K} \text {, deviation } \\
\text { inlet temperature } \pm 0.1 \mathrm{~K} . \mathrm{T}_{\text {out }}-\mathrm{T}_{\text {in }}>1.5 \mathrm{~K}, \mathrm{~T}_{\mathrm{m}}-\mathrm{T}_{\text {amb }} \text { at } \eta_{0} \pm 3 \mathrm{~K} \text {. } \\
\text { Conditioning phase minimum } 15 \text { min and measurement phase } \\
\text { minimum } 15 \text { min. }\end{array}$ \\
\hline & AS/NZS 2712 & \\
\hline
\end{tabular}

From a different point of view the whole quality system of the solar thermal market and the linking of the participants should be observed. The quality system refers to the interaction of several players involved in the market with the aim to provide a high quality for a service or a product.

The core of a national quality system includes the national standards body, which standards and norms are developed as a working basis in technical committees, the national meteorology institute that guarantees the traceability of measurements on fundamental and natural constants, and finally a national accreditation body which ensures that the various actors meet a particular certified property. For example, certification bodies in Libya are accredited if 
they meet the requirements of the ISO/IEC 17065, while in Europe they are accredited if they meet the requirements of the EN45011-45013 and thus possess the ability required for attestation of conformity. Solar thermal test laboratories work closely with the certification authorities and apply the developed specific norms and standards. Laboratories must ensure traceability of your measurements and that they should be in accordance with DIN EN ISO/IEC17025, which includes the quality standard ISO9001:2008 and additional requirements.

The return of the metrics of testing laboratories is usually with the help of calibration laboratories that specialize on certain measures and areas, and this in turn are accredited and ensure traceability at national metrology institute. Another member of a quality system is the academic sector with universities and colleges for all the sectors of a quality system either inquiring or educating participants. In training centers installers and planners are trained and educated for the technical requirements.

Consumer associations express the interests of consumers and buyers, while the interests of the industry are represented mainlyby the trade associations. The network comprises a functional quality system as a key player to the manufacturer, who will produce its products according to the current state of the art and the applicable standards. Links are essentially the service providers of the quality assurance system who examine products, certify and calibrate measuring instruments used in the production process. Another player is the group of importers and exporters, and foreign investors who are doing business on the national market.

An expansion of the national viewing horizon allows employees or participation in national bodies and organizations, so as to achieve international recognition of certification, test results and standards and to network with the various institutions of a quality assurance system internationally.

\section{REQUIREMENTS FOR SOLAR THERMAL TEST LABORATORIES}

The implementation and the business operation of a solar thermal test facility is one important element within the specific market. To ensure the quality of the products and to attend the role of an observer on the market a test center has to fulfill a number of requirements. Besides the necessary technical equipment and the implementation of tests in accordance with the various national and international standards the laboratory has to realize a quality management system to guarantee the quality of tests and services. On the basis of the technical equipment, the testing scope and the implemented quality management system the test laboratory can achieve an accreditation according to ISO/IEC17025 as proof for independent third party testing. Besides the testing of products a solar thermal test laboratory can also contribute to $R \& D$ projects, installer seminars, expert seminars and can act as a competence center 
for all kinds of questions in the matter of solar energy.

\subsection{Implementation of a solar test centre in a functioning quality infrastructure}

The term quality infrastructure [QI] refers to the interaction of several players involved in a specific market with the aim to provide a high quality for a product or a service. The concept of QI includes all the involved stakeholders and participants of the quality process in the market. The term QI refers to all aspects of metrology, standardization, testing, quality management, certification and accreditation that have an impact on conformity assessment. This includes both public and private institutions and the regulatory framework within which they operate.

In Figure 1 the interaction of the stakeholders of a national QI is schematically shown. In general the core of a national quality system includes the national standards body, which is developing standards and guidelines as a working basis in technical committees, the national meteorology institute, that guarantees the traceability of measurements to fundamental and natural constants, and finally a national accreditation body which ensures that the various actors meet a particular certified property. Most of the accreditation bodies of the countries are recognized worldwide by the International Laboratory Accreditation Cooperation [ILAC] at a different status. The international standard for the general requirements of accreditation bodies is the standard ISO / IEC 17011. Certification bodies in Europe can be accredited if they meet the requirements according to the EN 45011 for product certification and thus possess the ability required for attestation of conformity. At international level the standard ISO / IEC 17065 is in force for certifying products, processes and services. Solar thermal test centres work closely together with the certification authorities and apply the developed specific technical regulations and standards. Test centre must ensure the traceability of the measurements and shall be accredited in accordance with the standard ISO / IEC 17025, which is based on the quality standard ISO 9001 and includes also additional requirements. The return of the metrics of testing laboratories is usually done with the help of accredited calibration laboratories that are specialized in certain measures and working fields, and those laboratories in turn are accredited and ensure traceability to the national fundamental and natural constants. Another member of a quality system is the academic sector, namely basic and higher education. Universities and colleges are providing educational services for all the sectors of a quality system either inquiring or educating participants. Consumer associations express the interests of consumers and buyers, while the interests of the industry are represented mainly by the trade associations. The whole network comprises a functional quality system as a key factor for the manufacturer, who will produce products according to the current state of the art and the applicable standards. 
Table (3). Certification and Standardization Potentials of RCREEE Members [4]

\begin{tabular}{|c|c|c|c|c|c|c|c|c|c|c|}
\hline Policy Indicators & $\stackrel{\frac{\pi}{2}}{\stackrel{2}{\lrcorner}}$ & $\cdot \frac{\sqrt[\pi]{a}}{\Xi}$ & 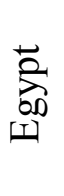 & 宽 & 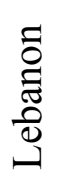 & 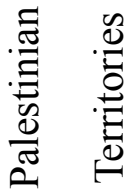 & 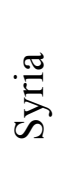 & $\frac{\pi}{\frac{\pi}{\bar{D}}}$ & $\underset{\overparen{D}}{\stackrel{D}{D}}$ & $\begin{array}{l}8 \\
\circlearrowright \\
0 \\
\stackrel{0}{0}\end{array}$ \\
\hline Standardization & $x$ & $\checkmark$ & $\checkmark$ & $\checkmark$ & $\checkmark$ & $\checkmark$ & $\checkmark$ & $\checkmark$ & $x$ & $\checkmark$ \\
\hline Testing & $\checkmark$ & $\checkmark$ & $\checkmark$ & $\checkmark$ & $\checkmark$ & $\checkmark$ & $\checkmark$ & $x$ & $x$ & $\checkmark$ \\
\hline Certification & $x$ & $\checkmark$ & $x$ & $x$ & $\checkmark$ & $x$ & $x$ & $x$ & $x$ & $x$ \\
\hline $\begin{array}{l}\text { Quality control } \\
\text { regulations and rules }\end{array}$ & $x$ & $\checkmark$ & $x$ & $x$ & $\checkmark$ & $x$ & $x$ & $x$ & $x$ & $\checkmark$ \\
\hline R\&D Programs/Fund & $x$ & $x$ & $x$ & $x$ & $x$ & $x$ & $x$ & $x$ & $x$ & $x$ \\
\hline Policies and Regulation & $x$ & $\checkmark$ & $\checkmark$ & $\checkmark$ & $x$ & $x$ & $x$ & $\checkmark$ & $x$ & $\checkmark$ \\
\hline Governmental initiatives & $x$ & $\checkmark$ & $\checkmark$ & $\checkmark$ & $\checkmark$ & $x$ & $\checkmark$ & $x$ & $x$ & $\checkmark$ \\
\hline $\begin{array}{l}\text { Trade movements \& } \\
\text { export regulations }\end{array}$ & $x$ & $\checkmark$ & $x$ & $\checkmark$ & $x$ & $x$ & $x$ & $x$ & $x$ & $x$ \\
\hline Taxes & $x$ & $\checkmark$ & $x$ & $x$ & $x$ & $x$ & $x$ & $x$ & $x$ & $x$ \\
\hline $\begin{array}{l}\text { Law enforcement (to } \\
\text { install SWH) }\end{array}$ & $x$ & $\checkmark$ & $x$ & $x$ & $x$ & $x$ & $x$ & $x$ & $x$ & $x$ \\
\hline
\end{tabular}

$$
\checkmark \text { :existing } \quad \mathbf{x}: \text { missing }
$$

With an expansion of the national horizon to a global view the leveling of international recognition of certification, test results and standards may be achieved. For this reason the networking of the various institutions and organizations of a quality infrastructure should cooperate internationally and acknowledge the results, reports and documents amongst themselves according to international standards as a basis.

\section{CONCLUSION}

The international and national standards for solar thermal collectors and components are a competent medium for the quality assurance of a solar thermal market. For this reason the interaction and linking between the different stakeholders of a national or international quality assurance system has to be established.

For test laboratories the adoption of an accreditation according to the standard ISO/ IEC17025 is important to get international recognition and reputation. Based on an accreditation and the specific testing scope of the test laboratory participation at various certification schemes is possible. A high degree of consumer information and protection can be established by means of tested products or even further advanced a certified product.

Besides the standardization of solar thermal products the fields of awareness rising and an adapted policy framework are necessary to encourage a promising 


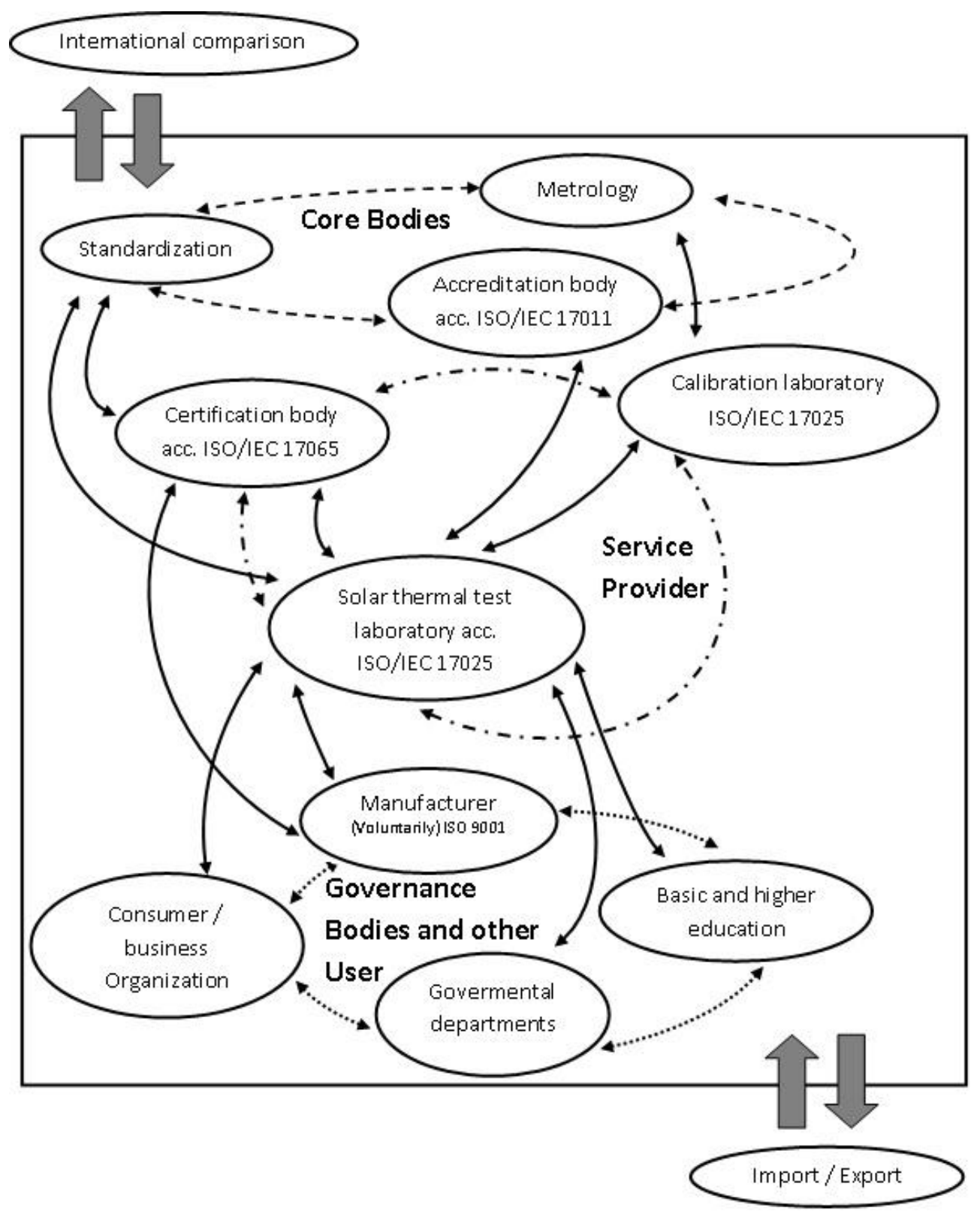

Figure (1). Example for the interaction of the stakeholders of a national quality infrastructure [QI] from the perspective of a solar thermal test laboratory (a certification model)

solar thermal market. The standardization process is important but is not enough by itself. There are complementarities to testing and certification processes that need to be considered.

As referred above, a STANDARD is designed to be used as a rule, guideline or definition. There can be two main categories:
- Technical standards: consisting of technical specifications or other strict criteria that ensure products, manufacturing processes and services meet fixed quality benchmarks. Furthermore test methods are usually part of technical standards. These test methods are used to check if requirements specified in the standard(s) 
are fulfilled and also to determine certain product characteristics such as performance.

- Management and leadership standards: provide a framework for a business to manage its business processes and activities (Quality Management Standards).

In the case of solar thermal, the specificities of the product and of the existing standards led to the creation of specialized testing laboratories or testing centers respectively for these products, providing an alternative to self-testing by manufacturers.

\section{REFERENCES}

[1]. Guide on Standardization and Quality Assurance for Solar Thermal - Global Solar Water Heating Market Transformation and Strengthening Initiative.

[2]. Solar KEYMARK - www.estif.org / solarkeymark
[3]. Solar Rating and Certification Corporation (SRCC), www.solar-rating.org

[4]. Solar Heaters Arab Mark and Certification Initiative, Prepared by: Ashraf Kraidy, Eng. E,MSc, Program Manager, RCREEE SHAMCI Network Coordinator.

Websites

- Solarthermalworld.com

- ESTIF.org

- Solar-rating.org

- QAiST IEE/08/593/SI2. 529236 Deliverable D 2.3 A guideline to the standard EN 12975

- CEN, European committee for standardization, 2006 "EN 12975-1:2006, Thermal solar systems and components Collectors - Part 1: Requirements"

- CEN, European committee for standardization, 2006 "EN 12975-2:2006, Thermal solar systems and components Collectors - Part 2: Test methods"

- $\quad w w w . s o l a r k e y m a r k . o r g$

- $\quad$ www.cen.eu 